\title{
Service life assessment of exterior lime-pozzolan renders containing ceramic powder
}

\author{
J. Maděra, J. Kočí, E. Vejmelková, M. Čáchová, \\ M. Jerman \& R. Černý \\ Department of Materials Engineering and Chemistry, \\ Faculty of Civil Engineering, Czech Technical University in Prague, \\ Czech Republic
}

\begin{abstract}
Three different types of hollow-brick walls provided with different exterior limebased renders containing ceramic powder are investigated in the paper. The influence of the differences in the material composition of building envelope on the service life of exterior renders is analysed. Conclusions on the most advantageous material composition with respect to the service life of exterior renders are drawn.

Keywords: computational simulation, heat and moisture transport, service life assessment, lime-pozzolan renders.
\end{abstract}

\section{Introduction}

Currently, exterior renders are mostly comprehended as finishing and architectural layers of building constructions. However, previously, the primary function of these renders was to protect the load-bearing construction against mechanical and other environmental effects. One of the typical environmental effects is the frost damage. Nowadays, the necessity of frost resistance of the load-bearing construction is voided by applying contact thermal insulation systems on the exterior side. In this case, the exterior render does not have to meet the requirements of frost resistance as well. However, with increasing thermal performance of new building materials, such as advanced hollow bricks filled with thermal insulation, the external thermal insulation is not necessary and therefore the frost resistance of exterior renders must be taken under consideration all over again. 
The design of new renders is determined by technical regulations and requirements. However, the composition itself is very often directed by construction companies. First of all, these companies try to produce a complete range of building products, and last but not least, they are trying to minimize the waste in particular production processes and in this way to maximize the effectiveness of the whole production. Therefore, waste materials from one production process may appear as input material in other process. A typical example of this cost-saving measures is a production of brick rubbing dust as a waste in advanced hollow clay brick production process, which is subsequently used as an admixture in the composition of renders.

The newly developed renders must meet high requirements in terms of chemical composition, but also the durability plays a crucial role. The durability of the render is in a close relation with the warranty given by the producer. The warranty is usually given for 10 to 15 years. The estimation of durability is, however, very complex and challenging task which depends on material composition of building envelope [1] and its climatic load. Proper combination of load-bearing structure with respective render may significantly increase the render's service life. Therefore, already in the design process of new renders, their durability is to be tested using experimental/computational approach.

In this paper, in the experimental part all necessary thermal properties are determined at first and the frost resistance of investigated renders is tested. In the computational part, the number of freeze/thaw cycles under a particular climate is evaluated. Comparing the results of experimental and computational approaches allows the estimation of the service life of studied renders in terms of their frost resistance.

\section{Experimental data acquisition}

For the service life analysis three different renders were chosen. The composition of studied renders is shown in Tab. 1.

Table 1: The composition of studied renders.

\begin{tabular}{|c|c|c|c|c|c|c|c|c|}
\hline \multirow[b]{2}{*}{ Material } & \multirow{2}{*}{$\begin{array}{c}\text { Brick } \\
\text { powder } \\
(\mathrm{kg})\end{array}$} & \multirow[b]{2}{*}{$\begin{array}{c}\text { Lime } \\
(\mathrm{kg})\end{array}$} & \multirow[b]{2}{*}{$\begin{array}{c}\text { Cement } \\
(\mathrm{kg})\end{array}$} & \multicolumn{3}{|c|}{ Sand (kg) } & \multirow{2}{*}{$\begin{array}{l}\text { Flow } \\
\text { diam. } \\
(\mathrm{mm})\end{array}$} & \multirow[b]{2}{*}{$\begin{array}{l}\text { Water } \\
\text { (L) }\end{array}$} \\
\hline & & & & $\begin{array}{c}0.3- \\
0.8\end{array}$ & $\begin{array}{c}0.6- \\
1.2\end{array}$ & $\begin{array}{c}1.0- \\
4.0\end{array}$ & & \\
\hline VCAR & 0.00 & 5.94 & 0.31 & 6.25 & 6.25 & 6.25 & 8 & 6.7 \\
\hline VCA3 & 1.25 & 4.75 & 0.25 & 6.25 & 6.25 & 6.25 & & 6.5 \\
\hline VCA6 & 3.13 & 2.97 & 0.16 & 6.25 & 6.25 & 6.25 & $\underline{0}$ & 5.2 \\
\hline
\end{tabular}

The lime-based render contained different percentage of fine ground brick, which was produced as a waste by Heluz (Czech Republic). Its chemical composition is given in Tab. 2. This waste material is produced by grinding of calibrated ceramic thermal insulation blocks. The lime CL $90 \mathrm{~S}$ (Tab. 3) was produced by the company Čertovy schody a.s., the Portland cement was the CEM I $42.5 \mathrm{R}$ type. The reference material was pure lime render labelled as VCAR. 
Modified renders with an increasing content of ceramic were labelled VCA3 and VCA6.

Table 2: Chemical composition of finely ground brick.

\begin{tabular}{|c|c|c|c|c|c|c|c|c|c|}
\hline Component & $\mathrm{SiO}_{2}$ & $\mathrm{Al}_{2} \mathrm{O}_{3}$ & $\mathrm{Fe}_{2} \mathrm{O}_{3}$ & $\mathrm{CaO}$ & $\mathrm{MgO}$ & $\mathrm{K}_{2} \mathrm{O}$ & $\mathrm{Na}_{2} \mathrm{O}$ & $\mathrm{TiO}_{2}$ & $\mathrm{SO}_{3}$ \\
\hline Amount (\%) & 51.3 & 20.0 & 6.0 & 11.5 & 4.5 & 3.2 & 1.3 & 0.8 & 1.0 \\
\hline
\end{tabular}

Table 3: Chemical composition of lime.

\begin{tabular}{|c|c|c|c|c|c|c|c|}
\hline Component & $\mathrm{CaO}+\mathrm{MgO}$ & $\mathrm{MgO}$ & $\mathrm{CO}_{2}$ & $\mathrm{SO}_{3}$ & Free lime & Water & Air \\
\hline Amount (\%) & $\geq 90$ & $\leq 5$ & $\leq 4$ & $\leq 2$ & $\geq 80$ & $\leq 2$ & $\leq 12$ \\
\hline
\end{tabular}

The basic material properties of studied renders are given in Tab. 4, where $\rho$ is the bulk density, $\psi$ the porosity, $c$ the specific heat capacity, $\mu_{d r y}$ cup the water vapor diffusion resistance factor in dry conditions, $\mu_{\text {wet cup }}$ the water vapor diffusion resistance factor in wet air, $\lambda_{\text {dry }}$ the thermal conductivity in dry conditions, $\lambda_{\text {sat }}$ the thermal conductivity in water saturated conditions, $\kappa_{a p p}$ is the apparent moisture diffusivity. All of these parameters are stored in the material database [2].

Table 4: Material characteristics of renders.

\begin{tabular}{|c|c|c|c|}
\hline & VCAR & VCA3 & VCA6 \\
\hline$\rho\left(\mathrm{kg} / \mathrm{m}^{3}\right)$ & 1644 & 1655 & 1713 \\
\hline$\psi(\%)$ & 33.4 & 35.0 & 35.6 \\
\hline$c(\mathrm{~J} / \mathrm{kgK})$ & 919 & 903 & 831 \\
\hline$\mu_{\text {dry cup }}(-)$ & 20.28 & 21.83 & 27.26 \\
\hline$\mu_{\text {wet cup }}(-)$ & 6.41 & 6.96 & 9.23 \\
\hline$\lambda_{\text {dry }}(\mathrm{W} / \mathrm{mK})$ & 0.694 & 0.676 & 0.669 \\
\hline$\lambda_{\text {sat }}(\mathrm{W} / \mathrm{mK})$ & 2.320 & 2.386 & 2.415 \\
\hline$\kappa_{\text {app }}\left(\mathrm{m}^{2} / \mathrm{s}\right)$ & $1.35 \mathrm{E}-06$ & $6.60 \mathrm{E}-07$ & $2.93 \mathrm{E}-07$ \\
\hline
\end{tabular}

Moisture diffusivity as a function of moisture content of different types of studied renders is shown in Fig. 1. The methodology for determination of this parameter is described in [3], for the processing of laboratory determined data Datasmoother [4] and K-spline software was used [5].

The frost resistance that is necessary for estimation of service life of studied renders was determined according to ČSN 722452 "Testing of frost resistance of mortar" [6]. The fully water saturated samples having dimensions $40 \mathrm{~mm}$ x $40 \mathrm{~mm}$ $\mathrm{x} 160 \mathrm{~mm}$ were dried on the surface and then placed into a plastic bag. Then, the samples were put into the freezer for at least 4 hours while the temperature was kept at $-20^{\circ} \mathrm{C}$. After removing from the freezer, the samples were placed in the laboratory conditions for 2 hours, where the temperature was maintained at $20 \pm$ 
$1{ }^{\circ} \mathrm{C}$, and then were put into water for 16 hours. This process was repeated until obvious damage was registered. The established number of freeze/thaw cycles is summarized in Tab. 5.

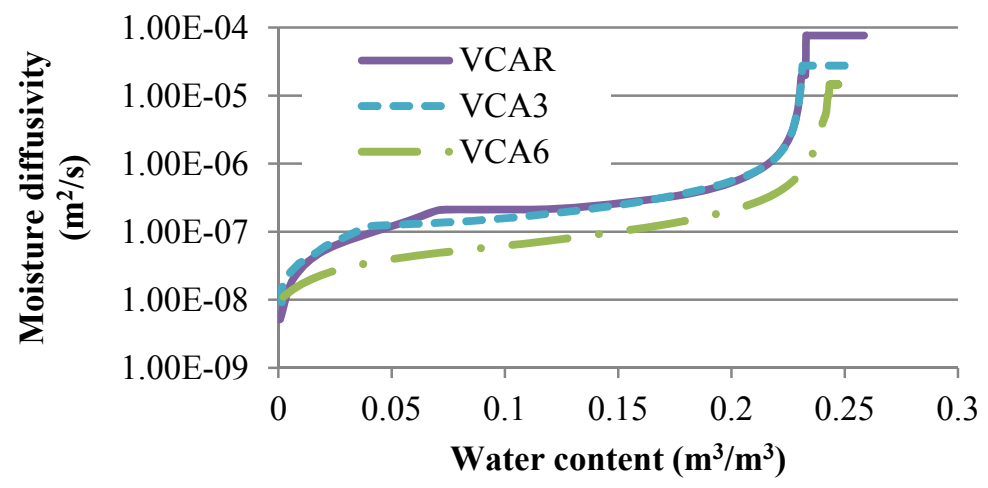

Figure 1: Moisture diffusivity of studied renders.

Table 5: Number of freeze/thaw cycles causing damage to the material.

\begin{tabular}{|l|c|c|c|}
\hline & VCAR & VCA3 & VCA6 \\
\hline Number of freezing cycles & 0 & 1 & 5 \\
\hline
\end{tabular}

The studied load-bearing structure was made from three types of advanced hollow clay bricks having voids filled with different insulation materials expanded polystyrene (EPS) and hydrophilic (HwFil) and hydrophobic mineral wool (HwFob). For the sake of simplification of the calculations, the homogenization principles were employed and homogenized material parameters were used (Tab. 6) [7, 8].

Table 6: Material parameters of advanced hollow bricks [7, 8].

\begin{tabular}{|c|c|c|c|}
\hline & $\begin{array}{c}\text { Expanded } \\
\text { polystyrene (EPS) }\end{array}$ & $\begin{array}{c}\text { Hydrophilic } \\
\text { mineral wool } \\
\text { (HwFil) }\end{array}$ & $\begin{array}{c}\text { Hydrophobic } \\
\text { mineral wool } \\
\text { (HwFob) }\end{array}$ \\
\hline$\rho\left(\mathrm{kg} / \mathrm{m}^{3}\right)$ & 793 & 651 & 667 \\
\hline$\psi(\%)$ & 28.1 & 76.5 & 76.8 \\
\hline$c(\mathrm{~J} / \mathrm{kgK})$ & 1052 & 1022 & 1019 \\
\hline$\mu_{\text {dry cup }}(-)$ & 12.8 & 5.39 & 4.7 \\
\hline$\mu_{\text {wet cup }}(-)$ & 10.58 & 2.76 & 2.6 \\
\hline$\lambda_{\text {dry }}(\mathrm{W} / \mathrm{mK})$ & 0.084 & 0.076 & 0.076 \\
\hline$\lambda_{\text {sat }}(\mathrm{W} / \mathrm{mK})$ & 0.187 & 0.848 & 0.828 \\
\hline$\kappa_{\text {app }}\left(\mathrm{m}^{2} / \mathrm{s}\right)$ & $8.55 \mathrm{E}-11$ & $1.089 \mathrm{E}-6$ & $1.82 \mathrm{E}-08$ \\
\hline
\end{tabular}




\section{Computational model}

The service life analysis of studied renders was carried out on blockworks made from advanced hollow bricks with different cavity fillers. The thickness of the load-bearing construction was $500 \mathrm{~mm}$. Interior plasters were made of VCAR having thickness $10 \mathrm{~mm}$, the exterior renders were $30 \mathrm{~mm}$ thick.

For the investigation of hygrothermal performance of studied constructions a modified Künzel's mathematical model was used [9]. The modified mathematical model is able to distinguish more precisely between liquid and gaseous phase of moisture transport and thus brings higher accuracy to the calculations [10]. Balance equations are expressed as:

$$
\begin{gathered}
\frac{d \rho_{v}}{d \phi} \frac{\partial \phi}{\partial t}=\operatorname{div}\left[\left(B\left(D_{w} \rho_{w} \frac{d w}{d \phi}\right)+A\left(\delta_{p} p_{s}\right)\right) \operatorname{grad} \phi+\left(\delta_{p} \phi \frac{d p_{s}}{d T}\right) \operatorname{grad} T\right] \\
\frac{d H}{d T} \frac{\partial T}{\partial t}=\operatorname{div}(\lambda \operatorname{grad} T)+L_{v} \operatorname{div}\left[\delta_{p} \operatorname{grad}\left(\phi p_{s}\right)\right]
\end{gathered}
$$

where $\rho_{v}$ is the partial density of moisture, $\varphi$ is the relative humidity, $\delta_{p}$ is the permeability of water vapor, $p_{s}$ is the partial pressure of saturated water vapor, $H$ is the enthalpy density, $L_{v}$ is the heat of evaporation, $\lambda$ is the thermal conductivity, $T$ is the temperature, $D_{w}$ is the total capillary transport coefficient, $\rho_{w}$ is the density of water and $w$ is the moisture content. The transition function assigns the weight to parameters $A$ and $B$ (being within the range of $0-1$ ) with the balance $A+B=1$ valid for every point of the curve.

The satisfactory combination of power functions reads [10]:

$$
\begin{gathered}
\left.B=32\left[\left(\frac{1}{\phi_{2}-\phi_{1}}\right)\left(\phi-\phi_{1}\right)\right]^{6} \text { for } \varphi=<90 ; 93.8\right), \\
B=1-32\left[\left(\frac{1}{\phi_{2}-\phi_{1}}\right)\left(\phi_{2}-\phi\right)\right]^{6} \text { for } \varphi=<93.8 ; 97.6>
\end{gathered}
$$

where $B=0$ for $\varphi<90 \%, B=1$ for $\varphi>97.6 \%, B \in<0 ; 1>$ according to (3) and (4) and $A=1-B$.

The solution of the transport problem leads to necessity of solving partial differential equations. These equations were solved by finite element approach using computer code SIFEL [11].

Boundary conditions in the interior were set constant as $21^{\circ} \mathrm{C}$ and $55 \%$ relative humidity. On the exterior side, the climatic load in a form of Test Reference Year (TRY) of two different locations, namely Prague-Karlov and Železná Ruda, were used. Prague is typical for its favorable weather conditions within the Czech Republic, whereas Železná Ruda is characteristic by its harsh mountain climate. The TRYs were obtained from the Czech Hydrometeorological Institute (CHMI) which is an official authority for climatology, hydrology and atmosphere quality in the Czech Republic. The weather data obtained from CHMI as well as other sources are stored in weather database [12]. The monthly values of temperature, relative humidity and precipitation for studied location are shown in Figs 2-4. 


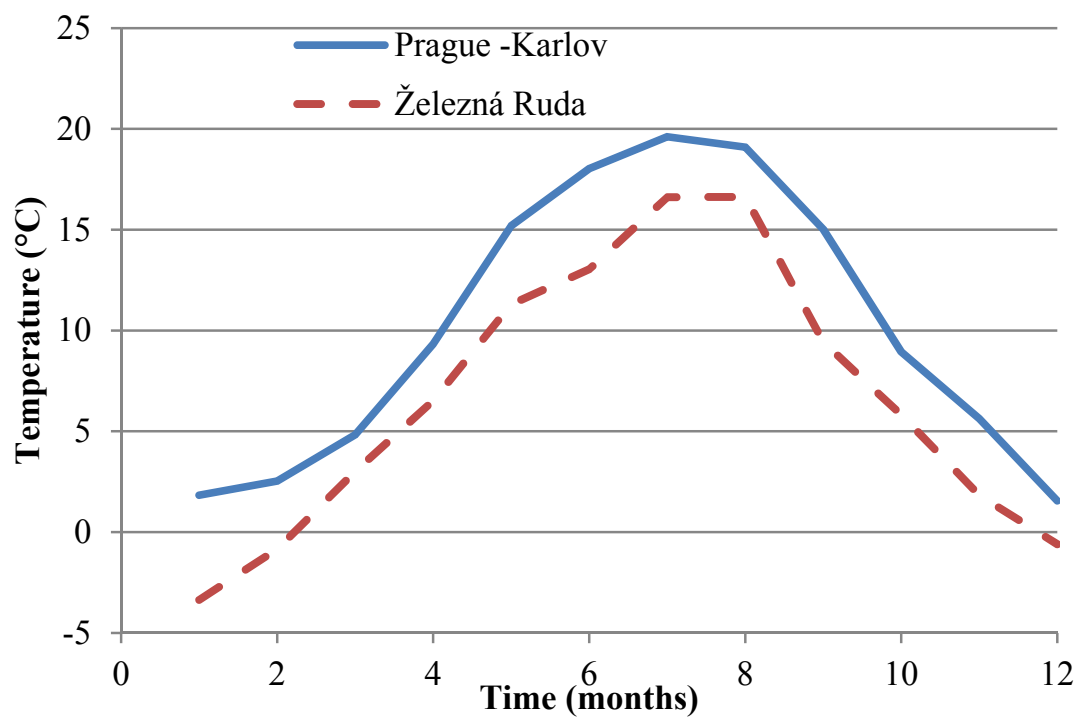

Figure 2: Average values of temperature.

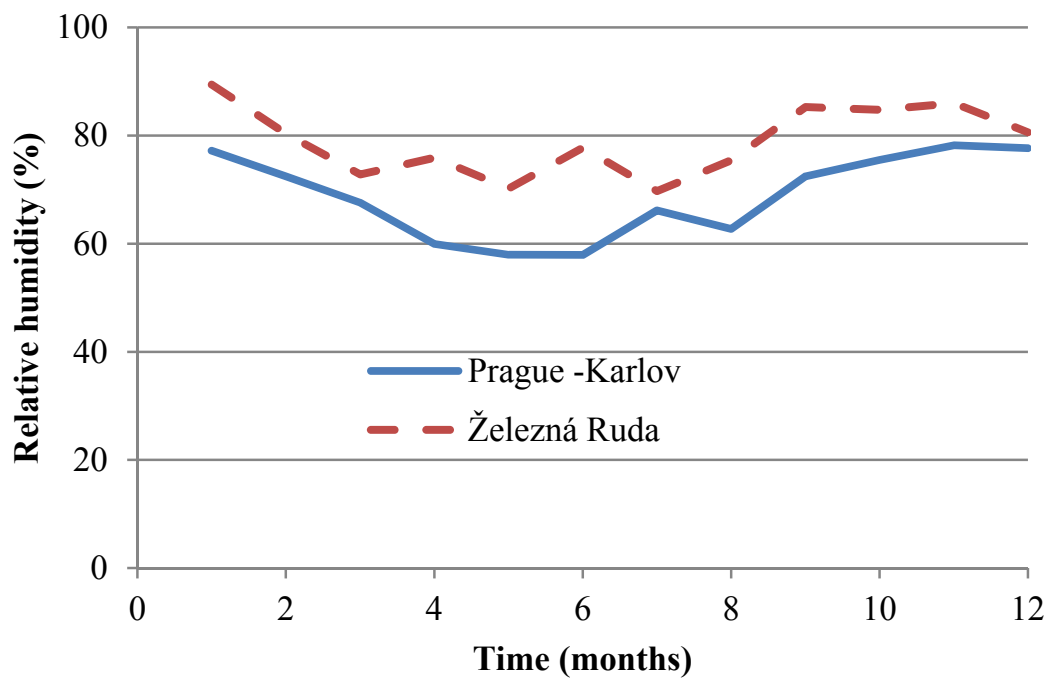

Figure 3: Average values of relative humidity. 


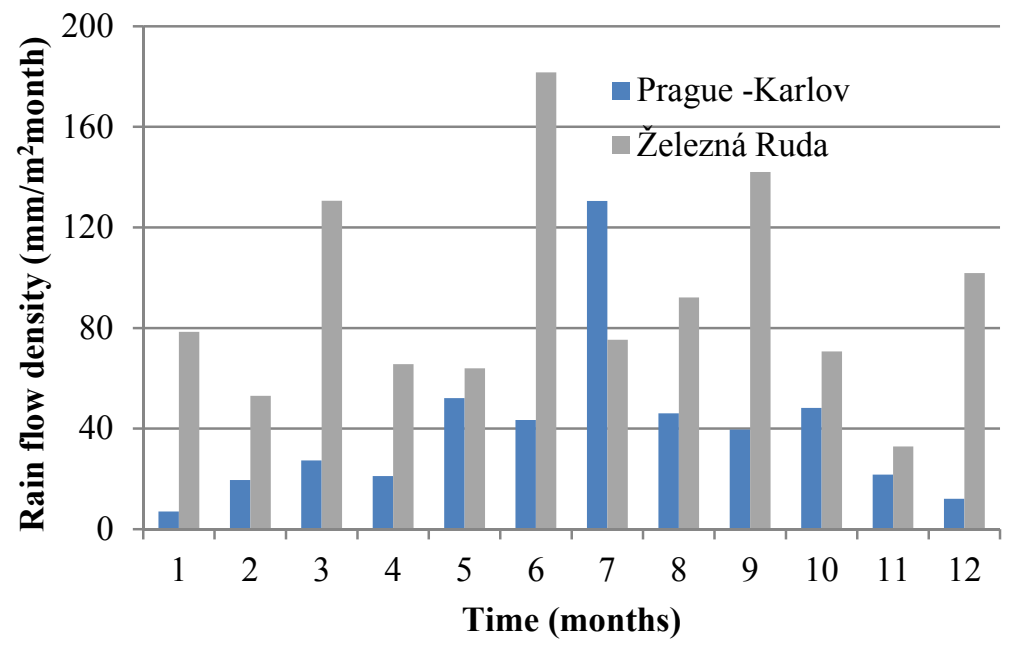

Figure 4: Rain flow density per month.

\section{Results and discussion}

The results of computational simulations were divided into sections according to the material of load-bearing construction. Each simulation was performed for 5 years. The assessment of service life analysis was carried out for the $5^{\text {th }}$ year of simulation. The process of determination of the number of freeze/thaw cycles in the surface layer of the construction based on simulation result is described in [13].

\subsection{Hollow brick filled with polystyrene}

The hygrothermal performance of all studied renders was very similar. Under the temperate climate of Prague, 7 freeze/thaw cycles were discovered in VCAR and VCA3 renders, the VCA6 exhibited 6 cycles (Fig. 5). A rapid increase of the presence of freeze/thaw cycles was registered under the climate of Železná Ruda. The amount of freeze/thaw cycles was varying between 53 and 57 for all the studied renders (see Fig. 6 for VCAR).

\subsection{Hollow brick filled with hydrophilic mineral wool}

The load-bearing construction made from hollow bricks filled with hydrophilic mineral wool showed slightly better performance undere severe climatic conditions of Železná Ruda. Comparing to the brick filled with polystyrene, the discovered number of freeze/thaw cycles was 48 in case of VCA6. The other renders VCAR and VCA3 (Fig. 8) showed 55 and 61 cycles, respectively. In Prague, the hygrothermal performance was very simular to the previous loadbearing construction (see Fig. 7 for VCA6). 


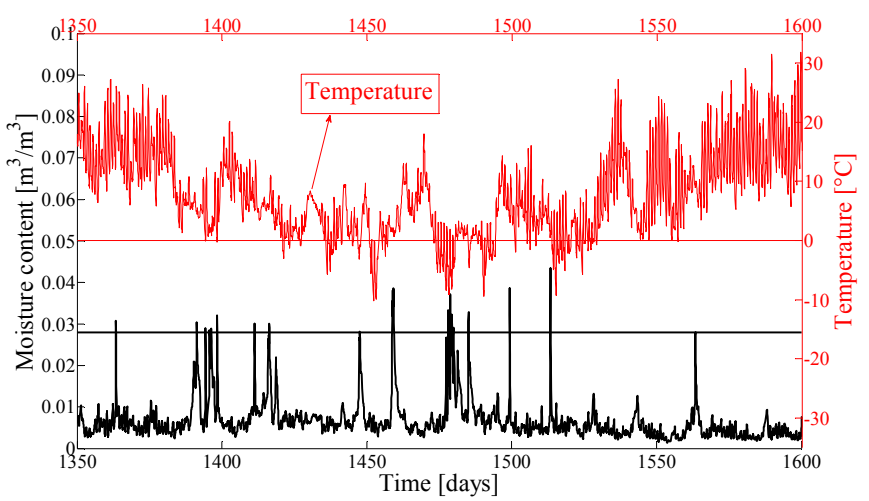

Figure 5: Time development of moisture content and temperature, VCA6, EPS, Praha-Karlov.

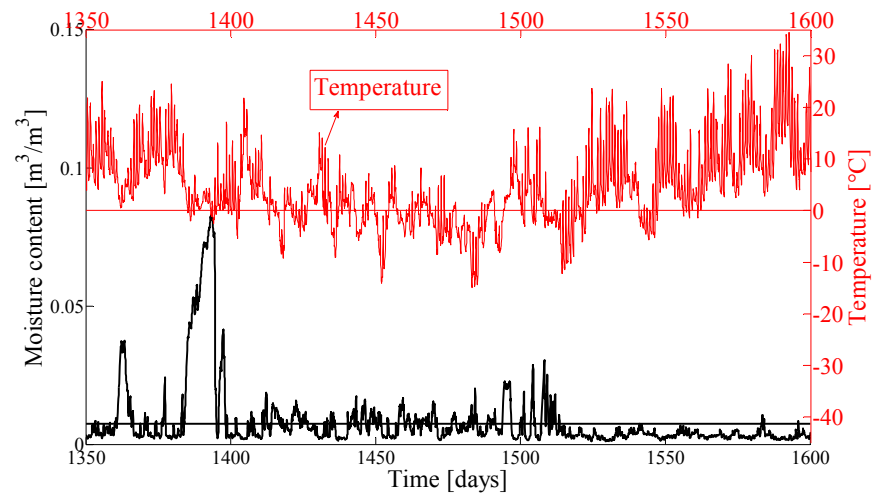

Figure 6: Time development of moisture content and temperature, VCAR, EPS, Železná Ruda.

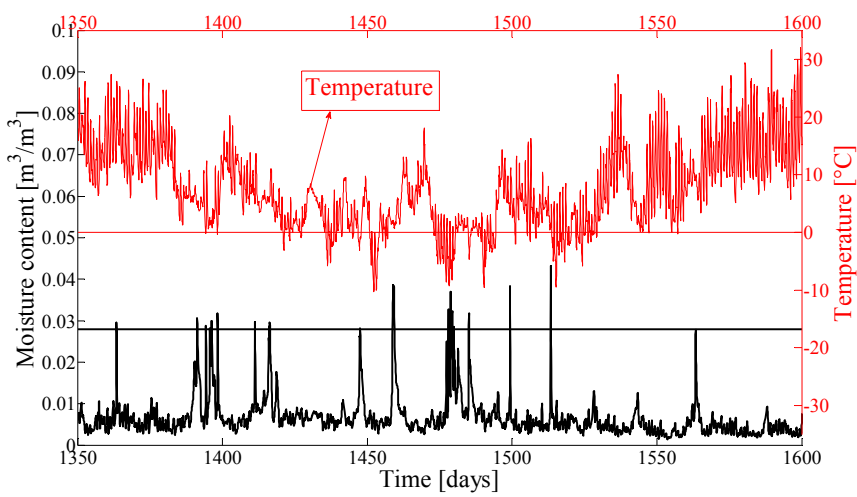

Figure 7: Time behavior of moisture content and temperature, VCA6, HFil, Praha-Karlov. 


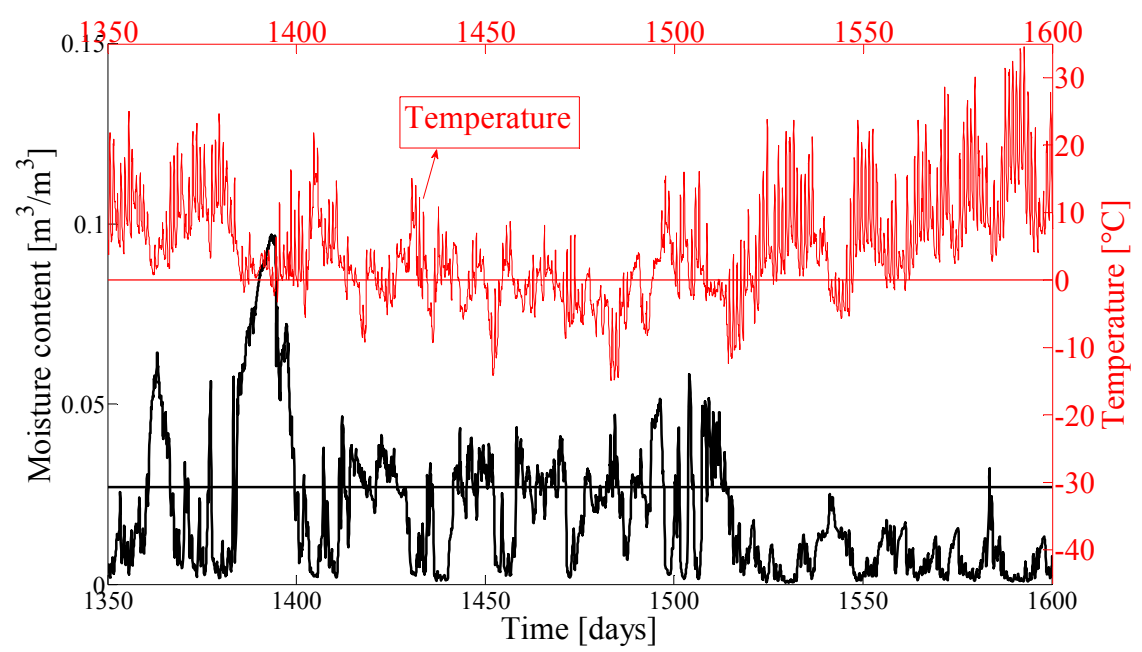

Figure 8: Time behavior of moisture content and temperature, VCA3, HFil Železná Ruda.

\subsection{Hollow brick filled with hydrophobic mineral wool}

In case of building envelope made from hollow bricks filled with hydrophobic mineral wool, the hygrothermal performance was almost identical to the one made of polystyrene-filled hollow bricks. The best performance was achieved by VCA6 render (Fig. 9) with 6 freeze/thaw cycles in Prague, 56 freeze/thaw cycles were discovered in VCAR and VCA3 (Fig. 10) in Železná Ruda.

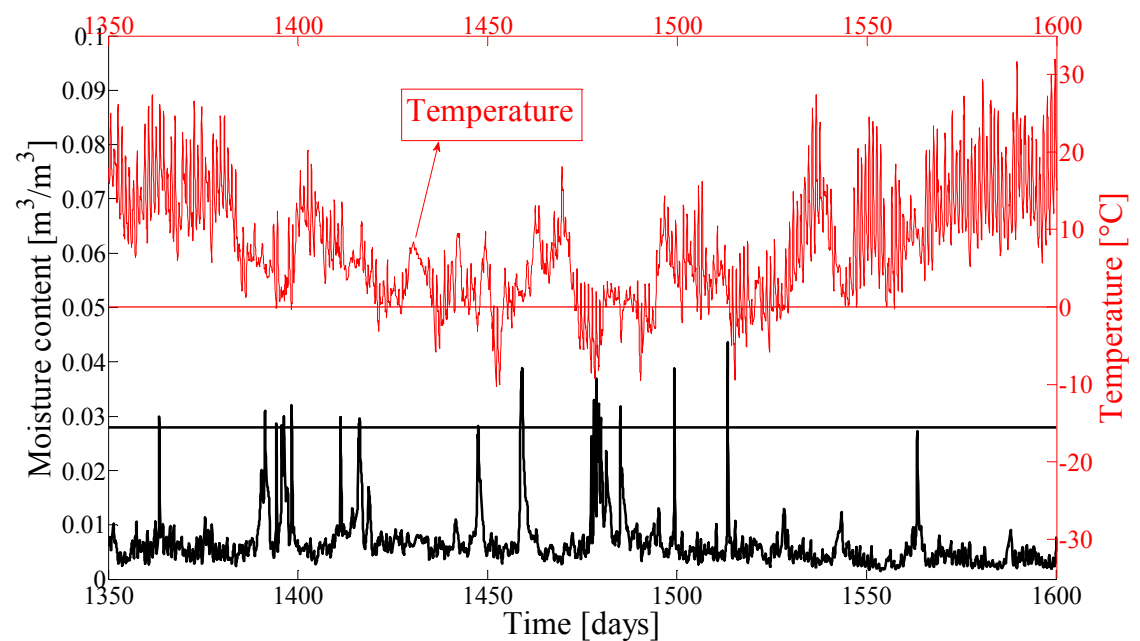

Figure 9: Time behavior of moisture content and temperature, VCA6, HFob, Praha-Karlov. 


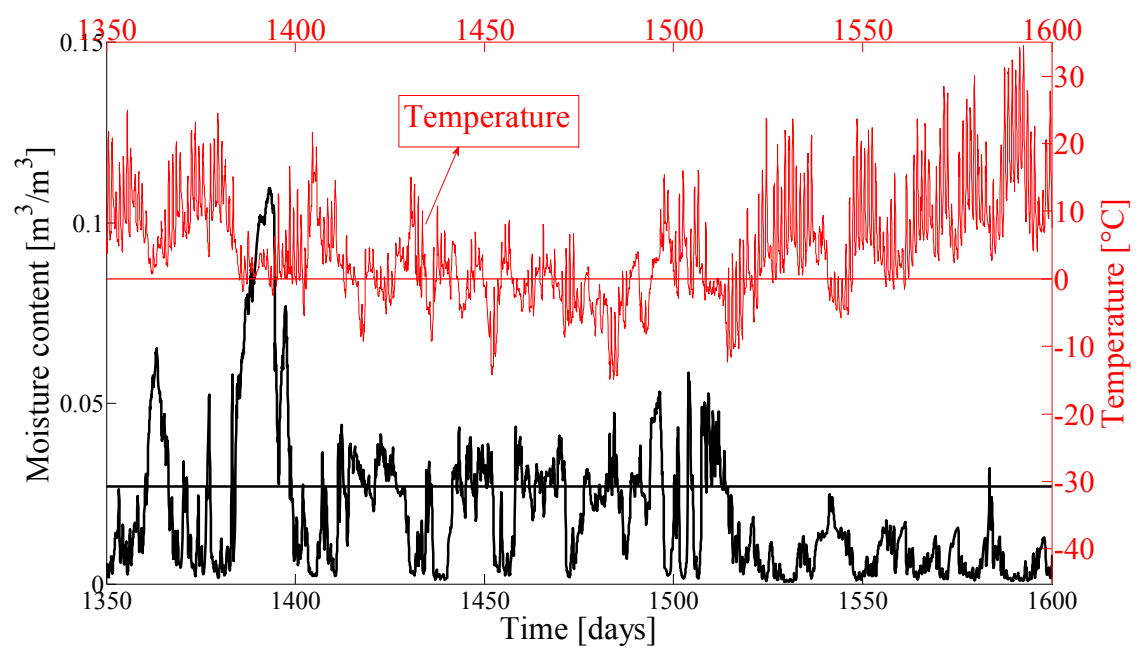

Figure 10: Time behavior of moisture content and temperature, VCA3, HFob, Železná Ruda.

\subsection{Summary of freeze/thaw cycles}

The total summary of discovered freeze/thaw cycles for each combination of loadbearing construction and exterior render is given in Tab. 7 .

Table 7: Number of discovered freeze/thaw cycles.

\begin{tabular}{|c|c|c|c|}
\hline & & Praha Karlov & Železná Ruda \\
\hline \multirow{3}{*}{ EPS } & VCAR & 7 & 57 \\
\cline { 2 - 4 } & VCA3 & 7 & 56 \\
\cline { 2 - 4 } & VCA6 & 5 & 53 \\
\hline \multirow{3}{*}{ HFil } & VCAR & 8 & 55 \\
\cline { 2 - 4 } & VCA3 & 7 & 61 \\
\cline { 2 - 4 } & VCA6 & 5 & 48 \\
\hline \multirow{3}{*}{ HFob } & VCAR & 7 & 56 \\
\cline { 2 - 4 } & VCA3 & 7 & 56 \\
\cline { 2 - 4 } & VCA6 & 6 & 51 \\
\hline
\end{tabular}

Comparing the experimentally determined number of freeze/thaw cycles in Tab. 5 with their computationally estimated amount in Tab. 7, it could be concluded, that service life of studied renders will be no longer than 1 year in Prague weather conditions. The studied types of renders are completely unsuitable for the severe localities such as Železná Ruda. According to presented results, the hygrothermal performance of all studied renders is very similar with only little effect of cavity filler of hollow brick. 


\section{Conclusions}

Three different exterior lime-based renders containing ceramic powder were investigated from the point of view of service life in different conditions, in this paper. The hygrothermal performance of studied renders was analysed for three different types of advanced hollow bricks. The results showed that none of the studied renders was suitable for a use in the exterior. The presented results also proved that there was inconsiderable effect of the filler of advanced hollow bricks on the hygrothermal performance of the renders. In a summary, the studied renders were found limited to the use as plasters in the interior only, where the materials are protected against freeze/thaw effects.

\section{Acknowledgement}

This research has been supported by Ministry of Industry and Trade of the Czech Republic, under project No. FR-TI4/014.

\section{References}

[1] Larbi, J.A. Microscopy applied to the diagnosis of the deterioration of brick masonry. Construction and Building Materials, 18, pp. 299-307, 2004.

[2] K. Ďurana, L. Fiala, J. Maděra, R. Černý, A Material Database for Computational Models of Heat, Moisture, Salt and Momentum Transport: Construction of the Code as an Input Module and Example of Application. AIP Conference Proceedings, 1558, pp. 976-979, 2013.

[3] Jerman, M., Keppert, M., Výborný, J., Černý, R., Hygric, thermal and durability properties of autoclaved aerated concrete. Construction and Building Materials. 41 (1), pp. 352-359, 2013.

[4] Kočí, J., Kočí, V., Durana, K., Maděra, J., Černý, R., Determination of Moisture-Dependent Moisture Diffusivity Using Smoothed Experimental Data. AIP Conference Proceedings, 1558, pp. 2038-2041, 2013.

[5] Kočí, J., Pavlík, Z., Černý, R. Comparison of Two Different Modes of Inverse Analysis Used For Determination of Moisture Diffusivity of Building Materials. Advanced Materials Research, 982, pp. 49-53, 2014.

[6] ČSN 72 2452, Testing of frost resistance of mortar. Czech Standardization Institute: Prague, 2005.

[7] Korecký, T., Jerman, M., Vejmelková, E., Černý, R., Homogenisation of Physical Parameters of Filled Hollow Brick Block, Stavebni obzor (online), 22 (2), s. pp. 44-47, 2013.

[8] Korecký, T., Vejmelková, E., Jerman, M., Černý, R., Determination of Physical properties of Filled Hollow Brick, Stavební obzor (online), 22 (10), s. pp. 254-257, 2013.

[9] Künzel, H. M., Simultaneous Heat and Moisture Transport in Building Components, PhD Thesis, IRB Verlag Stuttgart, 1995.

[10] Ďurana, K., Kočí, J., Maděra, J., Pokorný, J., Černý, R., Modification of the computational model of coupled heat and moisture transport: the transition 
70 Computational Methods and Experimental Measurements XVII

between the liquid and gaseous phases of water. AIP Conference Proceedings, 2014, In press.

[11] Kruis, J., Koudelka, T. \& Krejčí, T., Efficient computer implementation of coupled hydro-thermo-mechanical analysis. Mathematics and Computers in Simulation, 80, pp. 1578-1588, 2010.

[12] K. Ďurana, J. Maděra, R. Černý, Database of climatic data as a rewarding tool for inclusion of weather observations in computational service life assessments of historical buildings. WIT Transactions on the Built Environment, 131, pp. 245-256, 2013.

[13] Maděra, J., Kočí, V., Černý, R., Effect of thermal insulation on hygric and thermal conditions in the envelopes of renovated historical buildings. WIT Transactions on Engineering Sciences, 75, pp. 281-292, 2012. 